\title{
NATO's Military Intervention in Libya: Implications on Regional Security
}

\author{
Eustina Macheka
}

Department of Peace and Governance, Bindura University of Science Education, Zimbabwe

Kurebwa Jeffrey*

Department of Peace and Governance, Bindura University of Science Education, Zimbabwe

\begin{abstract}
The study sought to understand the justification of NATO's intervention in Libya and implications on regional security. Qualitative research methodology was used in the study. Primary and secondary data sources were used to collect data. The findings of the study indicated that NATO's military intervention in Libya was not justified and failed to promote peace and security. Research findings further showed that the intervention was based on selfinterest. The intentions of NATO in Libya were far-fetched and heavily undermined the doctrines of the Responsibility to Protect (R2P) and humanitarian intervention. The research findings indicated that NATO intervened in Libya for regime change, imperialism and to benefit from the oil resource. Libyan citizens benefitted nothing from the intervention. The study argues that Libyans suffered economic, socio-political and religious effects. The intervention by NATO fuelled civil wars, violence, religious conflicts and terrorism.
\end{abstract}

Keywords: NATO; Military intervention; Libya; Regional security; United nations security council; International relations; Civil war; Humanitarian intervention.

\section{(c) (1) CC BY: Creative Commons Attribution License 4.0}

\section{Introduction}

Zartman and Rubin (2002), argued that the international community has a critical role to play in maintaining order and restoring justice. Peacekeeping missions as viewed by Bellamy and Williams (2011) now enjoy widespread legitimacy and have been remarkably successful in preventing the recurrence of violence. New conflict management and civilian protection tools have contributed to a marked decline in violent situations (Bellamy and Williams, 2011). Krasner (2012), argues that the $21^{\text {st }}$ century has recorded a conflict toll of above $50 \%$. This is because of the increasing number of civil wars, coups and terrorist attacks. The Libyan civil war and Syrian conflict are such good examples. However, Krasner (2012), in his analysis appreciates the increasing role of humanitarian intervention by international institutions such as the United Nations (UN) and NATO.

At the global level, NATO's role is to promote peace and security in war torn zones. Its roles include supporting, planning, programming and budgeting, assuring transparency, accountability, the adherence of the rule of law and good governance, supporting the establishment and sustaining processes such as force generation, recruiting, training, managing and development of personnel. Bush et al. (2011), indicates that the NATO has diversified its operations and missions since the early 1990s. Its main task is based on collective defence, crisis management and cooperative security. According to Bush et al. (2011), NATO maintains its presence on the basis of the United Nations Security Council Resolution (UNSCR) 1244. NATO also carries out disaster relief operations and missions to protect civilians against natural, technological and humanitarian disasters.

In Europe, NATO has responded to the refugee and migrant crisis. According to Goldstein (2012), NATO has operated in the Mediterranean Sea coasts on maritime situational awareness, counter terrorism and support capacity building at the sea. Currently, NATO is operating in Afghanistan and Kosovo. According to Krasner (2013), NATO has helped to create a professional and multi-ethnic Kosovo Security Force. Baldwin (2013), observes that approximately 4500 allied and Partner troops operate in Kosovo as part of the NATO's Kosovo Force (NKF) which continue to maintain a strong presence throughout the territory since 1999.

In Afghanistan is currently leading Resolute Support, a non-combat mission which provides training, advice and assistance to Afghan Security forces and institutions (Baldwin, 2013). The Resolute Support was launched on 1 January 2015. NATO has also intervened in the Syrian conflict. Beyond its Euro-Atlantic region, NATO has also provided support to the African Union (AU) in its peace keeping missions in the African continent. Krasner (2013) maintains that its support for the AU and conducting policing missions is based on the request of its Allies. However, scholars argue that when Libya was invaded, the African Union was not consulted. Nevertheless, as argued by Pattison (2011), NATO has assisted and supported the AU mission in Somalia (AMISOM). It provided aircraft for the peace keepers, capacity building and expert training support to the African Standby Force (ASF) at the AU's request.

The UNSCR 1970 provides that the goal of authorizing force and intervention in Libya was "to protect civilians and civilian populated areas under threat of attack." This, according to Walzer (2011) were efforts to have "an immediate ceasefire in Libya, including an end to the current attacks against civilians, which it said might constitute crimes against humanity, imposing a ban on all flights in the country's airspace a no-fly zone and tightened sanctions on the Gaddafi regime and its supporters. Libya's violent protests and uprisings as noted by Bush et al. (2011) 
began in mid-February 2011, paralleling similar political unrest in Tunisia and Egypt, among other Arab countries. On the international stage, Goldstein (2012), observes that the reaction was just as fast, as a number of multilateral organizations convened meetings to discuss the Libyan situation, including the Arab League and UNSC, EU, as well as NATO. UNSCR 1973 authorizing members to take 'all necessary measures to protect civilians' was passed on 17 March 2011 with 10 favourable votes and five abstentions (Brazil, China, Germany, India, and Russia). According to Krasner (2013), UNSCR 1973 was the result of skilful framing, including 'press harassment,' crafty compromises, de-marching coupled with time pressure, and the ability to display the moral high ground. The British and the French made use of their institutional privileges, bureaucratic expertise, and reputation to establish their competences.

Liberal internationalists, like Bellamy and Williams (2011) are of the view that the intervention reflected the power of the R2P doctrine since the end of the Cold War. NATO's intervention in Libya reflects how the world has become more committed to the protection of civilians. However, international norms now enshrine civilian protection and levels of violence are down, humanitarian interventions remain constrained by political and military realities. It is therefore against this background that the research seeks to understand whether NATO intervention of Libya was permissible or not.

\section{Literature Review and Theoretical Framework}

This study relies on the Just War theory to support the various arguments raised on NATO's military intervention of Libya. Just war theory is a doctrine, also referred to as a tradition, of military ethics studied by theologians, ethicists, policy makers, and military leaders. According to Walzer (2003), the purpose of the doctrine according is to ensure war is morally justifiable through a series of criteria, all of which must be met for a war to be considered just. Mchaman (2005), notes that the criteria are split into two groups which is the "right to go to war" (jus ad bellum) and "right conduct in war" (jus in bello). Crawford (2003), argues that the first group concerns the morality of going to war, and the second the moral conduct within war. Guttman and Rieff (1999), postulates that war, while terrible, is not always the worst option. As such this study seeks to understand the justification of NATO's military Intervention in Libya. Important responsibilities, undesirable outcomes, or preventable atrocities may justify war. According to Guthrie and Quinilan (2007), the Just War Theory is a synthesis of classical GrecoRoman, as well as Christian values. Aristotle, Cicero and St. Augustine influenced the development of the theory.

According to Walzer (2006), the Just war theory is imperative to the understanding of why countries invade each other. In this particular case the theory is applied to understand the justification for NATO's military intervention in Libya. This will enable the research to evaluate whether the military intervention was just or unjust as well to see whether it actually served its purpose (the responsibility to protect). Critical theorists such as Bush et al. (2011) dismissed the operation as a badly construed cover up for Western interests in the region. Krasner (2013), concluded that a 'neat realist narrative' with its focus on military capabilities and balance of power, could not account for the Libyan intervention. Barack Obama, former President of the United States of America, defended the intervention in Libya addressing a United Nations Conference, by indicating that, "There will be times when our safety is not directly threatened, but our interests and values are. In such cases, we should not be afraid to act."

The moral permissibility of the intervention in Libya according to Pattison (2011), largely turns on whether the situation was sufficiently serious at the time the intervention was launched (the just cause question), and or, what the predominant purposes of the intervention were (the right intention question). First, in regard to just cause, was the situation in Libya sufficiently serious to warrant humanitarian intervention? (Walzer, 2011), argues that "a military attack of the sort now in progress is defensible only in the most extreme cases." He argued that intervention was only permissible in response to acts that "shock the moral conscience of mankind."

\subsection{The Concept of Collective Security}

The international community according to Sharp (2013), is now wary of an international security agenda that may undermine states' sovereignty, violate human rights and destabilize the world at any given time. This study articulates that the principle of collective security provides rationality for a range of international organizations such as the UN, NATO, EU and OSCE which all attempt to uphold international peace and stability. This study highlights that in a system of collective security, the enemy is a threat to regional or international peace and security. If the system of collective security is international in its reach, a threat can originate in any region, and anywhere on the globe. According to Ghosh (2012), any nation within the regional or international system that commits aggression, imperils the peace, or grossly exceeds the bounds of civilised behaviour violates the norms of that collective security system and is subject to enforcement action.

According to Badyal (2012), collective security can be understood as a security arrangement, political, regional, or global, in which each state in the system accepts that the security of one is the concern of all, and therefore commits to a collective response to threats to, and breaches to peace. NATO as observed by Perkins (2001), was established during the Cold War to deter USSR expansion/aggression. Ghosh (2009) records that NATO was a classic military alliance and since the end of the Cold War, there is no threat to balance against. Collective security for NATO is meant to promote stability in Europe and elsewhere. This study sees NATO as a Democratic "club" where it safeguards the Allies' common values of democracy, individual liberty, the rule of law, and the peaceful resolution of disputes.

The provision of collective security, according to Schleicher (1963), was made in the charter of League of Nations which was established in 1919. Perkins (2001), postulates that the provision of Collective Security was made in the Charter of the United Nations established in 1945 and since then it is playing an important role in the maintenance of international peace by using the device of collective security. Collective Security is described by 
Sharp (2013), as a modern device of power management at international level. It has been designed as a deterrent against all possible attacks. Under this device all the nations take collective action against the aggressor. According to Perkins (2001), collective security clearly implies collective measures for dealing with threats to peace. According to Schleicher (1963), collective security is an arrangement among states in which all promise, in the event any member of the system engage in certain prohibited acts (war and aggression) against another member, to come to latter's assistance.

Walzer (2011) is of the view that although there may have been a just cause for humanitarian intervention, the situation in Libya did not seem to be serious enough to provide just cause for regime change or, more precisely, forcible regime change by an external party in support of a rebel movement. According to Adler and Pouliot (2001), the dangers of regime change are generally greater than that of humanitarian intervention: a larger number of innocent individuals are likely to be killed; the potential for instability in neighbouring regions is greater; and the costs of intervening in terms of the intervening soldiers' lives may be much higher, given the likely need for a significant deployment of ground troops. Given these harms, the bar for permissible regime change should be much higher than that for humanitarian intervention. However, the study will focus on whether the intention of the NATO's collective intervention was predominantly the protection of civilians, a humanitarian objective or the removal of Muammar Gaddafi.

\subsection{Humanitarian Intervention}

Modern humanitarian intervention was first conceived in the years following the end of the Cold War. The triumph of liberal democracy over Communism as noted by Crawford and Kuperman (2006) made Western leaders optimistic that they could solve the world's problems as never before. Military force that had long been held in check by superpower rivalry could now be unleashed to protect poor countries from aggression, repression, and hunger. The study notes that the shifting global landscape created new problems that required a collective action. Nationalist and ethnic conflicts in former Communist countries surged, and recurrent famines and instability hit much of Africa. A new and unsettled world order took shape. It was distinguished by the frequency and brutality of wars and the deliberate targeting of civilians. According to Adler-Nissen (2013), the emotional impact of these crises was heightened by new communications technologies that transmitted graphic images of human suffering across the world.

The USA policy on armed humanitarian intervention should be guided by several principles. Sovereignty remains the stabilizing force of the world order and a barrier to global anarchy. According to Collier (2009), armed intervention should be an option of last resort. Given the costs, risks, and the unpredictable consequences, it should be employed only when other measures have failed or when the speed and scale of atrocities outpaces slower instruments. The mission should be undertaken using means proportional to the conflict, and should be coupled with a realistic long-term political strategy to address the violence's root cause. Multilateral interventions are vastly preferable to unilateral ones. They offer both increased legitimacy and the promise that others will share the load. This study notes that the criterion for the use of force or military action is the same for humanitarian intervention or the R2P.

The R2P outlines that the UNSC should always be the first point of call on matters relating to military intervention. The United Nations Charter clearly provides for the use of force necessary to 'maintain or restore international peace and security' when authorized by the UNSC. According to Waltz (1979), the idea of collective security dates at least to the Peace of Westphalia, which included a collective security mechanism. However, as the High-level Panel notes 'the UNSC so far has been neither very consistent nor very effective in dealing with these cases, very often acting too late, too hesitantly or not at all'. According to Caney (2005), differing geo-political interests and agendas means that unanimous consensus of the permanent five members of the UNSC have rarely been achieved in respect of determinations of breaches of the peace, condemnations of acts of aggression or authorizations of the use of military force. This lack of agreement according to Chesterman (2011), leads to one of two consequences: inactivity and cries of Rwanda being repeated (the cases like Darfur and Zimbabwe) on the one hand and arguably morally legitimate, but illegal military interventions in for example Yugoslavia (by NATO), Liberia, and Sierra Leone (by the Economic Community of West African States) on the other.

The UK imposed itself as the 'penholder' or 'lead country' on Libya. As a UNSC member, it took upon itself the responsibility to draft resolutions and suggested the course of action. According to Zartman and Rubin (2002), the UK delegation, with its many seasoned diplomats and numerous 'experienced lawyers,' is widely recognized in the USA for its superior skills in legal technicalities that often bog down the UNSC. According to Pouliot (2010), one delegate observed that many provisions on sanctions, for instance, are 'cut and paste' from previous Britishdrafted resolutions and so was this resolution. As part of their struggle for competence, the British and French representatives also managed to twist UN procedures to their advantage.

The most striking example, which diplomats said 'contributed to the ability to pass Resolutions 1970 and 1973,' is the defection of Libyan Deputy Permanent Representative Ibrahim Dabbashi on 21 February 2011. Erlanger and Schimitt (2011), noted that through lobbying, the event allowed the P3 'to say: "Clearly the Libyan people want this (intervention)."' The British and French delegations asked Dabbashi to write a letter to the UNSC presidency, held by Brazil, calling for an immediate Council meeting. Pattison (2011) notes that on 26 February 20111, the UNSC unanimously passed Resolution 1970 (UN Doc. S/RES/1970), which invokes the R2P, demands an immediate end to hostilities under the authority of Chapter VII of the Charter, refers the situation to the ICC, establishes regimes of arms embargo, travel ban, and asset freeze, and finally expresses the Council's readiness to consider additional measures. One of the key turning points in the negotiations that led to the intervention came on 13 March 2011, 
when the Arab League called for a no-fly zone over the country. On 17 March 2011 the UN Security Council adopted Resolution 1973 authorizing member states to take forceful measures to protect Libyan civilians. Payandeh (2012), is of the view that NATO's actions to protect civilians were within the mandate.

\subsection{The Concept of R2P}

The R2P report was published in December 2001 and endorsed by the UN High level Panel on Threats, Challenges, and Change in 2004 and by former UN Secretary-General Kofi Annan in 2005. Voeten (2001), notes that China's official paper on UN reforms, published on June 7, 2005, noted that "each state shoulders the primary responsibility to protect its own population. When a massive humanitarian crisis occurs, it is the legitimate concern of the international community to ease and defuse the crisis." It went on to list the conditions and safeguards, including UNSC authorization, which form the core of R2P. Stahn (2007), notes that unanimous endorsement by world leaders in 2005 added clarity, rigour, and specificity, limiting the triggering events to war crimes, genocide, ethnic cleansing, and crimes against humanity, and thus realigning the emerging global political norm to existing categories of international legal crimes.

The International Commission on Intervention and State Sovereignty was established by the Government of Canada in September 2000 in the wake of the controversy surrounding NATOs bombing campaign in Kosovo. The catalyst as noted by Barnett and Duvall (2005), was Kofi Annan's question asking how the international community should respond to 'gross and systematic violations of human rights that affect every precept of our common humanity'. According to Neumann (2002), the Commission described their mandate as being: 'generally to build a broader understanding of the problem of reconciling intervention for human protection purposes and sovereignty and it was to try to develop a global political consensus on how to move from polemics and often paralysis towards action within the international system, particularly through the United Nations'.

R2P seeks to bring an end to gross and systematic violations of human rights. According to Lucas (2003), it proposes the authorization of 'action taken against a state or its leaders, without its or their consent, for purposes which are claimed to be humanitarian or protective'. The research notes that the R2P embraces the responsibility to prevent, the responsibility to react and the responsibility to rebuild. Furthermore Kuperman (2008), observes that 'prevention is the single most important dimension of the responsibility to protect'. The Commission as viewed by Hopf (2010), considers that effective conflict prevention requires 'knowledge of the fragility of the situation and the risks associated with it, understanding of the policy measures available that are capable of making a difference and willingness to apply those measures'. It labels these three criteria 'early warning', 'preventive toolbox' and 'political will'.

The first criterion of the R2P is referred to as the 'threshold criteria: just cause'. As noted by Bush et al. (2011) the R2P dictates that military intervention must be limited to situations of a large scale loss of life, actual or apprehended, with genocidal intent or not, which is the product either of deliberate state action, or state neglect or inability to act, or a failed state situation; or large scale 'ethnic cleansing', actual or apprehended, whether carried out by killing, forced expulsion, acts of terror or rape'.

The second criterion is 'right authority'. This according to Barnett and Duvall (2005), refers to the question of who should be the body to authorize any such intervention. The Commission devotes an entire chapter to this controversial and crucial criterion. In sum, three 'right authorities' are suggested: the Security Council, the General Assembly and Regional Organizations. The Commission notes that the Security Council should be the 'first point of call'. However, in view of the Council's past inability or unwillingness to fulfil the role expected of it, military intervention authorized by the General Assembly or Regional Organizations would have a 'high degree of legitimacy'.

The third criterion is 'right intention'. According to Crawford and Kuperman (2006), this means that the 'primary purpose of the intervention must be to halt or avert human suffering and that regime overthrow is not a legitimate reason for invoking the doctrine. The fourth criterion is 'last resort'. This, according to Kuperman (2013b), means that resort to force should only be used when every diplomatic and non-military avenue for the prevention or peaceful resolution of the humanitarian crises' has been explored. According to Pattison (2011), this is further qualified by the statement that this does not mean that the international community must have first tried every single possible option, but rather that there must be reasonable grounds for believing that, in all the circumstances, if the measure had been attempted it would not have succeeded.

The fifth criterion is 'proportional means'. Proportionality, according to Chesterman (2001), is a fundamental principle of jus ad bellum. Its inclusion in the list is uncontroversial. This, as viewed by Crawford and Kuperman (2006), dictates that military action can only be justified if it stands a reasonable chance of success. The Commission notes military intervention is not justified if actual protection cannot be achieved or if the consequences of embarking upon the intervention are likely to be worse than if there is no action at all. R2P's final responsibility is to rebuild as a post intervention strategy.

The United Nations has the responsibility to use appropriate diplomatic, humanitarian and other peaceful means. Chapters VI and VIII of the UN Charter (1945) states that:

We are prepared to take collective action, in a timely and decisive manner, through the Security Council, in accordance with the Charter, including Chapter VII, on a case-by-case basis and in co-operation with relevant regional organizations as appropriate, should peaceful means be inadequate and national authorities are manifestly failing to protect their populations from genocide, war crimes, ethnic cleansing and crimes against humanity. 
According to Daalder and Stravridis (2012), the use of force no matter how benevolent, enlightened, or impartial in intent has dramatic consequences. It shapes the struggle for power and helps to determine the outcome of political contests, which is why it is inherently controversial. According to Bellamy and Williams (2011), it is why international debates about Libya the first road test of the R2P coercive element also known as Pillar Three were understandably contentious. Pillar Three is defined as the responsibility of Member States to respond collectively in a timely and decisive manner when a State is manifestly failing to provide protection. Collier (2009) notes that while peaceful means of response are primarily preferred, should that prove inadequate to ensure protection, the international community should use more robust action: "no strategy for fulfilling the responsibility to protect would be complete without the possibility of collective enforcement measures, including through sanctions or coercive military action in extreme cases."

Libya as observed by Eagleton (2013) proved to be almost a textbook illustration justifying R2P principles, but its implementation also demonstrated the need for legitimacy criteria to guide decisions on authorising and overseeing international military intervention. The research also argues that the Libyan experience would also confirm that the debate on military interventions cannot avoid questions of regime legitimacy, state capacity, and state-building. Resolution 1973, adopted on March 17 by a 10-5 vote (China, Russia, Brazil, Germany, and India abstained), authorised the use of all necessary measures to protect civilians and civilian populated areas.

\section{Research Design and Methodology}

Qualitative research methodology was used for the study. Data was gathered using key informant interviews and documentary search. Key respondents were purposively selected from organisations such as human rights organisations, media, academia and military and diplomatic missions.

\section{Discussion of Findings}

This section is based on the key findings of the research. The statements presented in this section are entirely subjective opinions of the key informants who participated in the research. The views of the respondents include both positive and negative responses, to present as balanced and impartial a view as possible.

\subsection{Causes of the Libyan Civil War}

One academic who participated in the study justified the reasons behind the civil war in Libya. He argued that: "personalization of authority by the former President of Libya Muammar Gaddafi, corruption and underdevelopment especially in the Eastern part of Libya as well as human rights violations were the major reasons for the war."

The above argument was supported by the ZimRights respondent who indicated that: "Gaddafi ruled over Libya without a constitution but a small green book called the Arab Jamah Riyah.This gave him power to ride on people's rights which later on led to the civil war."

A membe of the Zimbabwe National Army who has been involved in peace keeping missions also sees Gaddafi's authoritarian rule as the major cause of the Libyan civil war. He reflects that back in 1974, Gaddafi ordered that anyone alleged to be forming a political party would be executed. He stated that:

"From a political point of view Gaddafi was not at all democratic as he did not entertain the multiparty system and did not practice good governance. This was also considered to be a further violation of human rights as there was no political freedom of any sort."

According to Krasner (2013), corruption and underdevelopment caused disgruntlement among Libyan citizens thereby triggering the civil war. Gross human rights violations and abuses in Libya had a hand in the Libyan civil war and also contemplated intervention by NATO forces. According to Earlanger (2013) people where protesting against dictactorship and a democratic rule was the major outcry. As such one can therefore say that the causes of the civil war was deeply rooted in the perceived reppressive Gaddafi regime.

\subsection{Reasons for NATO's Intervention in Libya}

The respondents who participated in the study gave varying arguments on the reasons behind NATOs intervention. One respondent indicated that:

"The major reason was to protect the innocent civilians against the gross human rights violations, violence and abuses. The intervention was a measure of addressing human rights abuses and ensuring that innocent civilians that includes the women and children do not become victims of war and are not traumatized by the war situation."

A former Ambassador who participated in the study blamed NATO's intervention on neo-imperialism. He argued that:

"Imperialism and the advancement of the Western agenda caused the Libyan civil war. The intervention was nothing to do with a humanitarian mission but a typical regime change agenda where they wanted to depose Gaddafi whom they labelled and dictactor. The rise of the rebels was premeditated and was sponsored by the West. The need to impose Western democracy saw the Western funding ammunition to the NTC rebels and what the rebels failed to see was the bigger picture of the Western motive of controlling Libya's resources where she was one of the leading producers of oil." 
According to Bellamy and Williams (2011), the resource curse have seen Western countries indirectly participating in the scramble of Africa hiding in the names of humanitarian intervention and responsibility to protect as was done by NATO in Libya. Pouliot (2011), goes on to describe it as 'Western democratization of the world,' and 'regime change agenda.' According to Walzer (2011), humanitarian intervention always has the 'potential of becoming a tool for the interference by the strong in the affairs of the weak, with humanitarian considerations providing a veneer to justify such intervention'. Further, as postulated by Pouliot (2008), the legitimization of the use of unauthorized force on 'humanitarian' grounds by way of camouflaging the interventionist policies of the West is a well-acknowledged concern of the South.

\subsection{Justification of NATO's Military Intervention}

A respondent from the Zimbabwe National Army Colonel justified the military intervention as it was aimed at mantaining peace and security in a conflict zone. He stated that:

"A responsive measure from the UN and NATO institutions was a necessary evil so as to calm the situation in Libya. Peace keeping missions are meant to protect innocent civilians from harm, conflict resolution and peace building."

A respondent from the media organisation was of the view that th intervention was not justified. He mentioned that:

'If they had civilians at heart why then did they opt for an air strike?' Seemingly yet far from what transpired the purpose of the intervention was to address gross human rights violations which were believed to be conducted by the Gadaffi regime."

A respondent from the academia argued that the intervention was not defensible and not beneficial to the people of Libya. He argued that:

"There were allegations of mass rape and the improper use of land mines as means of war which is tantamount to violations of human rights as well as executions of prisoners of war, murder and torture of injured soldiers as well as looting of private property and killing of civilians during the battle of Saiti."

Another respondent also argued that there was no basis for NATO to intervene in Libya. He observed that: "The first problem with the mainstream narrative is that it relies on two demonstrably false premises: that Gaddafi initiated the violence by targeting peaceful protesters and that NATO's intervention aimed primarily to protect civilians. Contrary to most contemporaneous Western reporting, many Libyan protesters were armed and violent from the first day of the uprising in Benghazi."

A respondent from the human rights organisation also indicated that:

"NATO's military intervention was not justified as even the death toll rose following its air strikes. The intervention failed dismally to address human rights challenges as there was continued loss of lives. Once a strong economic country was now a country in a big economic crisis. Families were destroyed and displaced. Innocent civilians were denied their right to life following the unorganized airstrikes. Many people were injured, properties and infrastructure was destroyed and this left Libya at a very unstable condition. As such the Libyans benefitted if nothing at all from the military intervention."

The intervention was not permissable as it did not promote peace or protect civilians. According to Pattison (2011), thousands of civilians were killed during the air strike as it could not distinguish between the enemy and the innocent civilians. According to Kuperman (2013a), NATO backed and supported the rebel group which was not in accordance of the UNSCR 1973 and not within the confines of humanitarian intervention and R2P. NATO provided for the high-precision strike capabilities that the rebel commanders needed. Krasner (2013), also observed that the rebels were also rapidly improving their operations, especially in combat coordination, due to covert deployment of foreign military advisors and special agents from both France and Britain who trained the rebels and provided tactical intelligence for the NATO aircraft bombing forces. On 20 October 20111 Gaddafi was killed and on 27 October the Security Council adopted Resolution 2016, terminating the protection of civilians and the no-fly zone of Resolution 1973.

According to the UNHRC (2012), the traditional UN principle of impartiality implies that when the Security Council authorizes the use of force in situations of armed conflict, unless otherwise specified, the intervening states should remain neutral towards the political aims of the parties in the conflict. According to Baldwin (2013), the legal basis for NATO air strikes in this phase was arguably consent by the rebels as the new effective government of Libya, rather than Resolution 1973. But neither the UN mandate nor consent would provide a basis for NATO's use of force to assist the rebels with the offensive. While Resolution 1973 had the defensive purpose of protecting civilians, consent from the rebels would only be relevant once they had secured sufficient control of Libyan territory. Moreover, there is general agreement that the right of 'intervention by invitation' does not apply in cases of civil war. Payandeh (2012) argues that while it is easy to understand that NATO for military and political reasons wanted to overcome the stalemate between Gaddafi and the rebels, the air support for the Libyan rebels to advance on Gaddafi-held territories went beyond the mandate of Resolution 1973 and thus violated the prohibition against the use of force under the UN Charter article 2(4). 


\subsection{The Effects of NATO's Military Intervention}

The effects of NATO's military intervention can be divided into socio-economic, political and religious effects. All the key informants who participated in the study agreed that the military intervention had a lot of implications. Violence, death and destruction of infrastructure also emerged to be one the key disastrous effect raised by the key informants during the research. A former Ambassador indicated that;

"Can one put out fire with fire/Was an air strike the most appropriate measure to undertake to protect innocent civilians?"

A respondent from the human rights organisation mentioned that:

"The military intervention displaced people from their original homes. Families, property and infrastructure were destroyed. There was an undesirable rate of loss of lives. The violent situation left people especially women and children traumatized. Innocent civilians became victims of war. However, the democratic election of July 2012, to some extent brought to power a moderate, secular coalition government a stark change from Gaddafi's four decades of dictatorship."

Political unrest as observed by all the key informants was further heightened. According to a media respondent:

"There was no proper disarmament and the rebels continued to attack and cause disorder in Libya even after the intervention. The killing of Gaddafi only created more rilvaries between Gaddafi loyalists and the rebels which further saw continued attacks and death tolls. This also further promulgated religious conflicts."

Valentino (2011), observes that in the immediate wake of victory, the rebels perpetrated scores of reprisal killings, in addition to torturing, beating, and arbitrarily detaining thousands of suspected Gaddafi supporters. Krasner (2013), characterized this behaviour as "a trend of killings, looting and other abuses committed by armed anti-Gaddafi fighters who consider themselves above the law." According to Goldstein (2012), the French physician in Benghazi, estimated that "more than 2,000 deaths" occurred in Benghazi and its surroundings during his stay yet the Human Rights Watch documented only 233 deaths across all of Libya. According to Eagleton (2013), the international press also reported incorrectly, that Gaddafi's air force was indiscriminately bombing civilians in Benghazi and Tripoli. The government as noted by Chivers (2011) did attempt to intimidate the rebels by promising to be relentless in pursuing them. For example, on February 20, 2011, Gaddafi son Saif al-Islam declared that "we will fight to the last man and woman and bullet." Two days later, Gaddafi warned that he would deploy forces to tribal regions to "sanitize Libya an inch at a time" and "clear them of these rats," as he referred to the rebels. This rhetoric, however, never translated into reprisal targeting of civilians.

\subsection{Implications of NATO's Intervention on Regional Peace and Security}

NATO's intervention in Libya brought a lot of regional conflicts. All the respondents who participated in the study agreed were in support of this view. A former Ambassador indicated that:

"NATO's intervention in Libya has not only brought about instability such as xenophobia and racial segregation. It has also promulgated the rise of Islamic fundamentalism against Western democracy and opened space for terrorism."

An academic who participated in the study also mentioned that:

"Rebels expelled 30,000 (mostly black) residents from Tawerga, and burned or looted their homes and shops on grounds that some of them allegedly had been 'mercenaries' in the government's attacks on nearby Misurata."

A respondent from a human rights organisation indicated that:

"The ramification of this racial violence has been nationwide. For the more than one million African guest workers who came to oil-rich Libya seeking their fortunes, it has meant terror. These innocent migrant labourers were singled out by ordinary Libyans and rebels who believed they are the enemy."

A respondent from a media house was of the view that:

"Beyond humanitarian and human rights concerns, post war Libya has a weak record on security and democratization. The new government has failed to disarm or bring under its control the dozens of militias that arose during the revolution. This failure has resulted in deadly turf battles between rival tribes and commanders, as well as a growing threat from radical Islamists."

According to Adler-Nissen (2013), radical Islamists and terrorist groups such as as Alqaeda, suppressed under Gaddafi, emerged during the revolution as some of the most competent rebels. The research also takes note of civil conflict in Syria which has exacerbated humanitarian suffering, sectarianism, and radical Islam in that country and its neighbours. According to this study possible courses of action in Syria cannot be contemplated without acknowledging that the crisis is also about relations with Iran, Russia, and China. Another negative regional impact has been the flow of weapons, liberated from Gaddafi's arsenal, to arms markets and radical Islamists beyond Mali UNSC (2012), Ironically, according to Bellamy and Williams (2011), advocates of intervention in Libya have claimed that such action was essential to sustain the momentum of the relatively peaceful Arab Spring revolutions in Tunisia and Egypt. Accordingly, it is difficult to identify any obvious benefit for the region or beyond from NATO's intervention in Libya.

\subsection{Lessons From the Libyan Civi War}

The respondents highlighted that NATO's intervention in Libya had taught the world some very important lessons. A former ambassador indicated that: 
"In as much as there was need to intervene in Libya, there was also a need to look at the role that Gaddafi played in the making of Libya. A practical appreciation should be made to what Gaddafi did for his people. He did more good to Libya and its citizens than harm. If one is to look at the current situation of Libya six years after NATO invaded Libya, and back in the time of Gaddafi one should be able to appreciate well Libya in the past than it is now. Instability and endless violence is now the order of the day in Libya. There is no more peace and development in Libya."

An academic who participated in the study also concurred with the above sentiments. He mentioned that:

"Most African countries relied on Libya for oil. Libya was also considered as one of the richest countries with a functional economy. It provided loans to most poor African countries to sustain their economies. Because of the civil war and the disastrous military intervention sales severely deteriorated. Libbyans are nolonger benefitting from their oil.",

According to Winter (2009), Gaddafi vowed that his own parents would not get a house until everyone in Libya has. All newlyweds would receive $\$ 60000$ Dinars (US\$50 000) from the government to buy their first apartment. A mother who gave birth to a child also received \$5 000 upfront as child benefit. Krasner (2013), also notes that education and medical treatment were for free in Libya. A portion of Libya oil sale was credited directly to the bank accounts of all citizens of Libya. Before the reign of Gaddafi only $25 \%$ of Libyans were literate and in his time the number rose to approximately $83 \%$. Pouliot (2010) in his analysis also noted that if Libyans could not find education and or medical facilities they needed in Libya, the government funded them to go abroad to get such assistance. Libyans taking up farming careers were given farm land, a farming house, equipment, seeds and livestock to kick start their projects. If a citizen of Libya could not secure employment after graduation, the state would pay the average salary of the profession as if he or she was employed. According to Western and Goldstein (2011), Libya had no external debt and its reserves amounted to $\$ 150$ billion. However, these were globally frozen. Gaddafi carried out the world's biggest irrigation project known as the Great Man-made River Project, to make water readily available throughout the desert country.

\section{Conclusions}

The main purpose of this research was to understand the justification for NATO's military intervention of Libya and the implications on regional security. The research findings described the intervention as a deceit measure of appearance versus reality. The research findings indicated that it appeared as if NATO intervened in Libya on humanitarian grounds in order to protect the civilians during the Libyan civil war yet in reality there was more to the intervention. The civil war in Libya according to Krasner (2013) was mainly a result of the need for a democratic rule in Libya and the end of Gaddafi's authoritarian regime. However, when NATO intervened in the name of the $\mathrm{R} 2 \mathrm{P}$, it supported and funded the rebels an act which is not in line with R2P. The findings of the study further indicated that NATO's intervention of Libya was a regime change agenda. The need to control Libya's oil resources also explains why NATO intervened in Libya. According to Pouliot (2011), the intervention was interest-based and had nothing to do with protection of civilians as evidenced by the loss of lives that occurred in Libya. Based on all these findings the research then disqualifies NATO intervention of Libya as justified and questions the moral permissibility of the intervention.

According to Erlanger and Schimitt (2011), once a peaceful and stable nation, Libya is now a torn and failed state. Many people died during the civil war and findings show that the airstrikes could not distinguish between the enemy and the victim leading to a high death rate. Many people were socially displaced and traumatized by the war. The findings also took note of the rise of racism attacks and xenophobia. The intervention promoted more rebellion and the rise of terrorists as well as religious conflicts. The research posits that human security is at the heart of R2P. Proper implementation of the R2P must be observed in order to protect the civilians from any sort of harm.

Before his assassination, Gaddafi had indicated that he would never go into exile. He indicated that he was going to die in Libya, a desert country which he had turned into a forest. According to Krasner (2013), Gaddafi also believed that no one really loved Libya except its citizens. He warned the people of Libya to extra-careful and warry of the Europeans and Americans as their interest was on oil. In one of his message to the people of Libya, Gaddafi indicated that:

"My message to you the people of Libya is they are helping you to kill me but you will pay the price because you will suffer. And my message to you America and Europe is, you will kill me but be ready to fight a never ending Terrorism. Before you realise your ignorance terrorists will be hitting at your doorstep." (Kuperman, 2012)

According to Adler-Nissen (2013), NATO's intervention has exacerbated terrorist activity and other forms of violence in the region and the northern half of Mali has become the largest territory controlled by Islamic extremists in the world. Mali's chaos also spread to other neighbours, spurring deadly ethnic conflict in Burkina Faso and the growth of radical Islamism in Niger.

\section{References}

Adler-Nissen, R. (2013). Symbolic power in European diplomacy: The struggle between national foreign services and the EU's external action service. Review of International Studies, 1(25): 220-67.

Adler, E. and Pouliot, V. (2001). International practices. International Theory, 3(1): 1-36.

Baldwin, D. (2013). Power and international relations. W. Carlsnaes., T. Risse., \& B.A. Simmons. Eds., Handbook of International Relations. 2nd edn: Sage: Thousand Oaks, CA. 
Barnett, M. and Duvall, R. (2005). Power in international politics. International Organisation, 59(1): 39-75.

Bellamy, A. J. and Williams, P. D. (2011). The New Politics of Protection? Côte d'Ivoire, Libya and the Responsibility to Protect. International Affairs.

Bush, R., Martiniello, G. and Mercer, C. (2011). Humanitarian imperialism. Review of African Political Economy, 38: 357-65.

Caney, S. (2005). Justice beyond borders. Oxford University Press: Oxford: London.

Chesterman, S. (2001). Just war or just peace? Humanitarian intervention and international law, Oxford Monographs in International Law. Oxford University Press: Oxford.

Chesterman, S. (2011). Leading from Behind: The responsibility to protect, the Obama doctrine, and humanitarian intervention after Libya, New York University School of Law, New York University Public Law and Legal Theory Working Papers. Paper 282. Available: www.lsr.nellco.org

Chivers, C. J. (2011). Libyan rebels don't really add up to an army. New York Times. 3.

Collier, P. (2009). War, guns and votes: Democracy in dangerous places. Oxford University Press: Oxford.

Crawford (2003). Contractual governance of deviant behavior. Journal of Law and Society Banner, 30(4): $479-505$.

Crawford and Kuperman, A. J. (2006). Gambling on humanitarian intervention: Moral hazard, rebellion, and civil war. Routledge: New York.

Daalder, S. and Stravridis, J. G. (2012). NATO's victory in Libya: The right way to run an intervention. Foreign Affairs, 2(1): 21-43.

Erlanger, S. and Schimitt, E. (2011). NATO set to take full control of Libyan campaign. New York Times. www.nytimes.com

Ghosh, B. (2012). NGOs, civil society and social reconstruction in contemporary India. Journal of Developing Society, 10(1): 21-45.

Goldstein, B. E. (2012). Collaborative resilience: Moving though crisis to opportunity. The MIT Press, Cambridge: Massachusets.

Guthrie, C. and Quinilan, M. (2007). Just war: just war tradition: ethics in modern warfare. Bloomsbery: London.

Guttman, R. and Rieff, D. E. (1999). Crimes of war: What the public should know. W.W. Norton and Company: England.

Hopf, T. (2010). The logic of habit in International Relations. European Journal of International Relations, 16(4): 539-61.

Krasner, S. D. (2012). Talking tough to Pakistan: How to end Islamabad's defiance. Foreign Affairs, $12:$ 1-87.

Krasner, S. D. (2013). New terrains: Sovereignty and alternative conceptions of power, M. Finnemore., \& J. Goldstein eds., Back to basics: State power in a contemporary world. Oxford University Press: Oxford.

Kuperman (2008). The moral hazard of humanitarian intervention: Lessons from the Balkans. International Studies Quarterly, 52(1): 203-334.

Kuperman (2012). Lessons from Libya: How not to intervene. Quarterly Journal: International Security, 10(2): 2143.

Kuperman (2013a). Lessons from Libya: How not to intervene. Policy Brief, Belfer Center for Science and International Affairs: Harvard Kennedy School.

Kuperman (2013b). A model humanitarian intervention? Reassessing NATO's Libya campaign. Quarterly Journal: International Security, 38(1): 105-36.

Lucas, G. R. (2003). The role of the International Community in Just War Tradition Confronting the Challenges of Humanitarian Intervention and Pre-emptive War. Journal of Military Ethics, 2(2): 122-44.

Mchaman, J. (2005). Just cause for war. Wiley Publishers: USA.

Neumann, I. B. (2002). Returning practice to the linguistic turn: The case of diplomacy. Millennium, Journal of International Studies, 31(3): 627-51.

Pattison, J. (2011). The Ethics of humanitarian intervention in Libya, Ethics \& international affairs. Oxford University Press: Oxford: London.

Payandeh, M. (2012). The United Nations, military intervention, and regime change in Libya. Virginia Journal of International Law Association, 21(7): 34-104.

Perkins, S. J. (2001). Global champions: Who's paying attention? Thunderbird International Business Review, 43(1): $1-168$.

Pouliot, V. (2008). The logic of practicality: A theory of practice of security communities. International Organization.

Pouliot, V. (2010). International security in practice: The politics of NATO-Russia diplomacy. Cambridge University Press: Cambridge.

Pouliot, V. (2011). The logic of practicality: A theory of practice of security communities. International Organisations, 16(2): 257-88.

Sharp (2013). Syria humanitarian assistance response plan. United Nations: Syria.

Stahn, C. (2007). Responsibility to protect: Political rhetoric or emerging legal norm? American Journal of International Law, 101(1): 99-120.

UNHRC (2012). 21st session of the human rights council. United Nations: New York.

UNSC (2012). United nations security council report. United Nations: New York.

Valentino, B. A. (2011). The true costs of humanitarian intervention: The hard truth about a noble notion. Foreign Affairs, 90(6): 5-15. 
Voeten, E. (2001). Outside options and the logic of Security Council action. American Political Science Review, 95: $845-58$

Waltz, K. N. (1979). Theory of international politics. McGraw-Hill: New York.

Walzer, M. (2003). Just and unjust wars. Palgrave: New York.

Walzer, M. (2006). Just and Unjust Wars. 4th edn: Basic Books: New York.

Walzer, M. (2011). The case against our attack on Libya. New Republic.

Western, J. and Goldstein, J. S. (2011). Humanitarian intervention comes of age: Lessons from Somalia to Libya. Foreign Affairs, 90(6): 56-145.

Winter, J. (2009). International commission on intervention and state sovereignty, the responsibility to protect. International Development Research Centre: Ottawa.

Zartman, I. W. and Rubin, J. Z. (2002). Power and negotiation. University of Michigan Press: Ann Arbor, MI. 